\title{
Studies on the effect of pulsed magnetic field on the productivity of algae grown in dye industry effluent
}

\begin{abstract}
Magnetic fields are capable of eliciting in vivo and in vitro effects in many biological systems. Increasing attention is being directed towards bio-electromagnetic stimulation using the low frequency pulsed magnetic fields (PMF). Currently, microalgae have been considered to be the most promising candidates for biomass production. PMF may affect organisms in both negative and positive manner which includes acceleration of growth and metabolism. The present study deals with the studies on the effect of pulsed magnetic field (PMF) on the productivity selected micro algae Desmococcus $s p$. grown in the dye industry effluent. Desmococcus $s p$. was grown in photo bioreactors (1L) with a pulsed magnetic field facility. The magnetic field is set in a circular form from which the solenoid coil system set to a highly homogenous sinusoidal magnetic field intensity of $3 \mathrm{mg}$ for a period of $4 \mathrm{hrs}$ duration per day for 12 days. Aeration and light (intensity 2000-3000lux) have been provided for $12 \mathrm{hr}$ per day. Division rate, growth studies and physicochemical parameters have been analyzed that gave positive results by reducing the $\mathrm{BOD}, \mathrm{COD}$ and the nitrates level in the effluent. By the end of the $12^{\text {th }}$ day the effluent colour changed and a two fold increase in the algal biomass productivity in the dye effluent treated with PMF exposure is observed.
\end{abstract}

Volume 3 Issue 5 - 2017

\author{
Sirisha K,' Suganya B,' Sivasubramanian V, ${ }^{2}$ \\ Vishal BS,' Swaminathan D,' Anand C Babu,' \\ Meyyappan $\mathrm{N}^{\prime}$ \\ 'Department of Chemical Engineering, Sri Venkateswara College \\ of Engineering, India \\ ${ }^{2}$ Phycospectrum Environmental Research Centre (PERC), India
}

Correspondence: Swaminathan D, Department of Chemical Engineering, Sri Venkateswara College of Engineering, Pennalur, Sriperumbudur, Tamilnadu, India-602117,

Email dswami@svce.ac.in

Received: October 28, 2016 | Published: July 31, 2017

Keywords: dye effluent, microalgae, pulsed magnetic field, division rate

Abbreviations: PMF, pulsed magnetic fields; BOD, biochemical oxygen demand; COD, chemical oxygen demand; TSS, total suspended solid; PERC, phycospectrum environmental research centre; MIM, madras institute of magnetobiology; TDS, total dissolved solid

\section{Introduction}

Water pollution has been a threat to living beings. The major contributors of water pollution are industries mainly dye, dairy, food, etc, Dye industry tops the chart by releasing $2-20 \%$ of its effluent in environmental components. ${ }^{1}$ Due to the ease and cost-effectiveness in synthesis, firmness, stability to light, temperature and microbial attack, the usage of synthetic dye have been increased in the textile and dyeing industries. ${ }^{1} 10-25 \%$ of the total world production of dyes is lost during dyeing process like desizing, scouring, bleaching, mercerizing and dyeing process. ${ }^{2}$ Figure 1 shows the pie chart of the water consumption in wet processing steps. Water usage in such processes can generate millions of gallons dye wastewater every day. The redundant usage of water significantly increases the discharge of dye effluent and thereby contaminate freshwater.

This results in the increase of Biochemical Oxygen Demand (BOD), Chemical Oxygen Demand (COD), Total Suspended Solid (TSS) and alteration of $\mathrm{pH}$. The variation in concentration of dissolved oxygen and change in $\mathrm{pH}$ in such cases will reduces the viability of living organisms (from microorganism to large mammals) present in the water. There are many problems associated with dye industry effluent like consumption of large amount of potable and industrial water, fuel and variety of chemicals in a long process sequence and discharge of untreated effluents. Wet processing creates the highest volume of wastewater from textile processing. ${ }^{1,3}$ Report states that more than 10,000 diverse dyes and pigments are currently available. Annual production of such dyes exceeded 0.7 million tons for textile industries. Out of that, 0.2 tons of these dyes are lost to effluents every year during the dyeing and finishing operations, due to the inefficiency of the dyeing process. ${ }^{3}$ Unfortunately, most of these dyes escape conventional wastewater treatment processes and persist in the environment as a result of their high stability to light, temperature, water, detergents, chemicals, soap and other parameters such as bleach and perspiration. ${ }^{4}$ Therefore, treatment of these industrial effluents is necessary prior to their final discharge to the environment. In general, wastewater treatment processes are categorized into three stages: preliminary (physical), primary (physical) treatment and secondary (biological) treatment. Wastewater should receive primary (physical removal/settling) and secondary (biological) treatment, which can be followed by disinfection before discharge. This may further require advanced processes (advanced or tertiary treatment) for special wastes (radioactive waste). When the effluent from secondary treatment is objectionable, a third level of treatment, tertiary treatment, can be employed. Table 1 gives broad characteristics of the parameters in various textile industry effluents.

Bio-treatment with microalgae has been an attractive method due to their photosynthetic capabilities, by converting solar energy into useful biomass and incorporating nutrients such as nitrogen and phosphorous causing Eutrophication. Among the existing technology includes catalytic oxidation, membrane filtration, sorption processes, coagulation/flocculation and bio treatment with aerobic, anaerobic bacteria, fungi etc., microalgae applications emerging field for dye effluent treatment in a natural and eco friendly way and is called Phycoremediation..$^{5-7}$ This technology can effectively manage a wide range of industrial effluents to achieve the following where other methods fail:

\section{i. Reduction in COD, BOD}


ii. Reduction in sludge formation

iii. More than $90 \%$ reduction in operating costs

iv. Less space requirement and no chemicals used

v. Degradation and De-colorization of dyes

vi. GHG emission reduction

Based on the origin, algae are broadly classified into

i. Fresh water algae and

ii. Marine algae

In comparison with marine algae, fresh water microalgae have the potential to clean the dye effluent. Major phylum division of freshwater algae, morphology, and index of biodiversity, colour, and motility is mentioned in Table 2. In our study, secondary treated dye effluent from textile industry, Tirupur city, was investigated for its ability to support growth of 4 freshwater microalgae species includes Chroococcus turgidus, Desmococcus olivaceous, Scenedesmus quadricauda and Chlorella vulgaris, Desmococcus olivaceous. One promising species, Desmococcus olivaceous was further investigated for studying the effect of pulsed magnetic field ${ }^{8,9}$ on growth and biochemical parameters which is extensively being employed in remediation of dye industry effluent. ${ }^{10,11}$ Desmococcus $s p$. is a common alga in the world which is a familiar plant on the walls and trunks, especially in both shaded and polluted habitats not occupied by lichen communities. ${ }^{12}$ It is a green algae (chlorophyta) which grows in freshwater environment and is green in colour due to the presence of chlorophyll-a and chlorophyll-b. ${ }^{13}$ The study of these species is carried out in the laboratory-Phycospectrum Environmental Research Centre (PERC), Chennai- INDIA.

The magnetic field facility has been provided by Madras Institute of Magnetobiology (MIM), Chennai- INDIA. A magnetic field is an effect of electric currents and magnetic materials and can be produced by moving electric charges. In day to day activities magnetic fields are encountered as a force created by permanent magnets. It is widely used in modern technology, particularly in electrical engineering and electro mechanics. ${ }^{14,15}$ When a current carrying wire is bent into a loop, the magnetic field concentrates from the inside while weakening it outside. Bending a wire into multiple closely spaced loops to form a coil or solenoid enhances this effect. A device formed around an iron core may act as an electromagnet, generating a strong, well-controlled magnetic field. ${ }^{14,16}$

Table I Textile industry waste water characteristics. ${ }^{7}$

\begin{tabular}{lllll}
\hline Parameters & Standard textile dye effluent & Cotton & Synthetic & Wool \\
\hline $\mathrm{pH}$ & $5.5-9.0$ & $8-12$ & $07-S e p$ & $3-10$ \\
BOD & $30-350 \mathrm{ppm}$ & $150-750 \mathrm{ppm}$ & $150-200 \mathrm{ppm}$ & $5000-8000 \mathrm{ppm}$ \\
COD & $100-250 \mathrm{ppm}$ & $200-2400 \mathrm{ppm}$ & $400-650 \mathrm{ppm}$ & $10,000-20,000 \mathrm{ppm}$ \\
TDS & $1500-2100 \mathrm{ppm}$ & $2100-7700 \mathrm{ppm}$ & $1060-1120 \mathrm{ppm}$ & $10,000-15,000 \mathrm{ppm}$ \\
\hline
\end{tabular}

Table 2 Division of freshwater algae microscopical appearance

\begin{tabular}{|c|c|c|c|c|c|}
\hline S. No & $\begin{array}{l}\text { Algae Division } \\
\text { (phylum) }\end{array}$ & $\begin{array}{l}\text { Index of } \\
\text { biodiversity }\end{array}$ & Typical colour & $\begin{array}{l}\text { Typical morphology of } \\
\text { freshwater species }\end{array}$ & $\begin{array}{l}\text { Motility (vegetative cells/ } \\
\text { colonies) }\end{array}$ \\
\hline I & $\begin{array}{l}\text { Blue-green algae } \\
\text { Cyanophyta }\end{array}$ & 297 & Blue-green & $\begin{array}{l}\text { Microscopic or visible-usually } \\
\text { colonial }\end{array}$ & $\begin{array}{l}\text { Buoyancy regulation some } \\
\text { can glide }\end{array}$ \\
\hline 2 & Green algae Chlorophyta & 992 & Grass green & $\begin{array}{l}\text { Microscopic or visible- } \\
\text { unicellular or filamentous } \\
\text { colonial }\end{array}$ & $\begin{array}{l}\text { Some unicells and colonies } \\
\text { with flagella }\end{array}$ \\
\hline
\end{tabular}

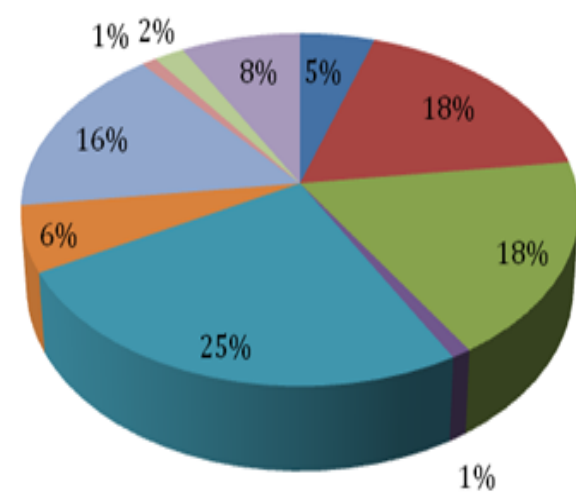

Figure I Water Consumption of components of wet processing of textiles.

\section{Desizing}

- Scouring

- Bleaching

- Mercerizing

- Dyeing

- Printing

a Finishing

- Carbonizing

Fulling

- Nutrilizing 
A long straight coil of wire called solenoids can be used to generate a nearly uniform magnetic field similar to that of a bar magnet. The field can be greatly strengthened by the addition of an iron core. ${ }^{16,17}$ A pulsed magnetic field is a strong electromagnet with a brief pulse of electric current through its windings. They can produce stronger magnetic fields than continuous magnets. Therefore by applying brief pulses of current, with time between the pulses to allow the heat to dissipate, stronger currents can be used and thus stronger magnetic fields can be generated. The magnetic field produced by pulsed field magnets can reach between 50 and $100 \mathrm{~T}$, and lasts several tens of milliseconds. ${ }^{8,9,15}$ In our experiment, a solenoid coil is used to generate pulsed magnetic field to the microalgae used for effluent treatment. Magnetobiology deals with interaction of biological systems with weak static and/or low-frequency ultra-low intensity electro-magnetic fields. The nature of biological effects of weak electromagnetic fields remains unclear as yet, despite numerous experimental data. In our experimental work we have been using low frequency ultralow intensity electro-magnetic field of $3 \mathrm{mG}$ for the cells ${ }^{11}$ of the microalgae to tolerate. The growth rate was monitored at regular intervals to come to a conclusion about the effect of the magnetic field on the microalgae as well as on the effluent.

\section{Materials and methods}

Secondary treated dye effluent was collected from a textile industry from Tirupur city, Tamilnadu-India. Physico-chemical parameters of the dye effluent have been analyzed before the treatment process. Collected dye effluent was treated with algae and without algae to check the activity of algal growth. Cells were counted using hemocytometer. Change in colour was observed which confirms the effectiveness of treating effluent using algae. Subsequently, based on the work by number of researchers, four different Algal species was cultured in the Phycospectrum Environmental Research Centre, PERC lab. A green alga, Desmococcus olivaceous has been chosen for the treatment of the effluent collected based on the screening process carried out for adaptation of species in the effluent. The screening was done by using reported BBM (Bold Basal Medium) medium. Bold Basal Medium was used for fresh water algae and has micro and macro nutrients for the growth of algae. Methodology is discussed as follows:

\section{Screening and selection of dye effluent treating algae}

Studies on growth pattern of each algae species $(10 \mathrm{~mL}, 100 \mathrm{~mL}$, 1L) has been carried out. Each culture was inoculated in $10 \mathrm{ml}$ different boiler tubes kept at slanted positions in order to provide maximum and constant light intensity of 24hours and 1800lux (measured via lux meter), to the micro-algae. Cell count was taken at regular interval and the algae which adapted well and grew fast have been selected for further process.

\section{Growth measurement}

Cell count of the micro algal culture has been estimated using Haemocytometer line method. The no. of cells present in the matrix present on the Haemocytometer is observed under microscope with $40 \mathrm{X}$ resolution and the no. of cells present has been noted.

\section{Exposure of pulsed magnetic field (PMF) on selected species}

Two photo-bioreactors have been installed initially, aided by aeration and light intensity of 2000-3000lux avg. Both the reactor is kept at an equal distance from the light source. One of the photo- bioreactor is integrated with Pulsed Magnetic Field (Test) and the other without the Pulsed Magnetic field exposure (Control). ${ }^{18}$ The Pulsed Magnetic Field has been connected to a voltmeter for current input and a signal generator which helps in the input of magnetic field strength, wave form and frequency. Figure 2 shows the setup of the pulsed magnetic field (blue) and a normal cane (green). The algae were exposed to light intensity in the range of 2000 to 3000 lux. Air was provided for the culture in the rate of $50 \mathrm{ml} / \mathrm{min}$. Light exposure and aeration was given for $12 \mathrm{hrs} /$ day basis for 12 days. The following conditions was maintained for throughout the treatment

i. Frequency: $1 \mathrm{~Hz}$ to $10 \mathrm{~Hz}$

ii. Field strength: $3 \mathrm{mG}$

iii. Wave form: Sinusoidal wave

iv. PMF exposure: 4hrs/ day (intermittent exposure)

a. $1 \mathrm{hr}$ (on-time)

b. $1 / 2 \mathrm{hr}$ (Off-time)

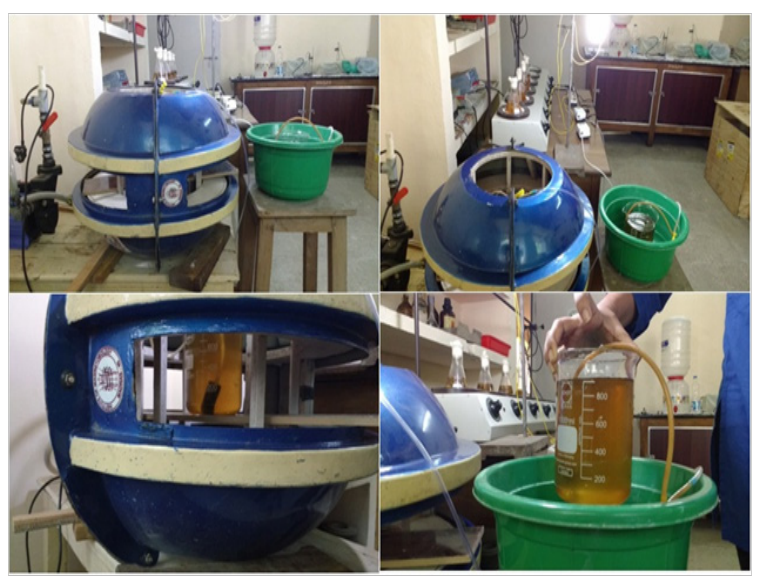

Figure 2 Pulsed magnetic field of $3 \mathrm{mg}$ setup.

\section{Physicochemical analysis}

The physico-chemical parameters such as BOD, COD, chloride, electrical conductivity, nitrate, $\mathrm{pH}$, phosphorous, TSS, Total Dissolved Solid (TDS), sulphatehave been analysed from the dye effluent before and after the treatment. It has been analysed by outsourcing (SMS Labs Private Limited, Thirumazhisai) the sample using standard methods (APHA 22 $2^{\text {nd }}$ EDI:2012)

\section{Results and discussion}

\section{Textile dye industry effluent collection and analysis}

The textile dye effluent collected from the Processing industry from Tirupur City, Tamil Nadu has been sent for physicochemical analysis ${ }^{19}$ before the phycoremediation process and the results obtained have been shown in the Table 3. It is clear from the results, high acidic conditions effluent do not favour the algae growth. Hence $\mathrm{pH}$ of 8 was maintained till the study phase. From the Table 3, we can conclude that the parameters are high and are not up to the standard levels set. Therefore, it is sent for bioremediation using microalgae. Out of the four algal species Chroococcus turgidus, Desmococcus olivaceous, Scenedesmus quadricauda and Chlorella vulgaris, Desmococcus olivaceous have been chosen based on its adaptation in the effluent. 


\section{Growth studies of Desmococcus olivaceous under the exposure of $3 \mathrm{mG}$ of pulsed magnetic field}

A mother culture has been maintained to carry out the experiment. Growth rate of the algae is measured in $10 \mathrm{ml}, 100 \mathrm{ml}$ and $1 \mathrm{~L}$ of BBM medium. After the maximum cell growth in the stock culture, $100 \mathrm{ml}$ of the culture is centrifuged and inoculated in 1L Effluent which have been exposed to $3 \mathrm{mG}$ of Pulsed Magnetic Field kept as (Test) and another $100 \mathrm{ml}$ of the culture from the stock is centrifuged and inoculated in 1Lt of effluent which has been kept as a (control) without any magnetic field exposure. Growth studies are measured using a Haemocytometer at regular intervals till the declining phase is attained. The above Table 4 and Figure 3 represent the growth kinetics of Desmococcus olivaceous in the effluent in both Test and Control. The growth of the algae is monitored till the $12^{\text {th }}$ day as there has been a two fold increase in the algal biomass productivity and the colour is changed from brown to green. The treated effluent has been sent for physicochemical analysis.

Table 3 Textile dye industry effluent analysis

\begin{tabular}{llll}
\hline S. No & Parameters & Unit & Result \\
\hline I & Total dissolved solids@ $180^{\circ} \mathrm{C}$ & $\mathrm{mg} / \mathrm{L}$ & 6897 \\
2 & Nitrate as $\mathrm{NO}_{3}$ & $\mathrm{mg} / \mathrm{L}$ & 77 \\
3 & Phosphate as $\mathrm{PO}_{4}$ & $\mathrm{mg} / \mathrm{L}$ & 4.3 \\
4 & COD & $\mathrm{mg} / \mathrm{L}$ & 202 \\
5 & BOD@ 27 ${ }^{\circ} \mathrm{C}$ for 3 days & $\mathrm{mg} / \mathrm{L}$ & 50 \\
6 & Total Suspended Solids@ $105^{\circ} \mathrm{C}$ & $\mathrm{mg} / \mathrm{L}$ & 7 \\
7 & Chloride as $\mathrm{Cl}$ & $\mathrm{mg} / \mathrm{L}$ & 3185 \\
8 & Sulphate as $\mathrm{SO}{ }_{4}$ & $\mathrm{mg} / \mathrm{L}$ & 519 \\
9 & PH@ $25^{\circ} \mathrm{C}$ & - & 2.82 \\
10 & Conductivity@25 & & 12130 \\
\hline
\end{tabular}

\section{Physicochemical parameters of the treated effluent}

The parameters of the effluent treated under PMF exposure (Test) and without PMF exposure (Control) have been analyzed and the result obtained is compared with the raw effluent. The Table 5 represent a comparative study of the physicochemical parameters ${ }^{19}$ of the raw effluent and the PMF exposed effluent. The result shows that the $\mathrm{pH}$ has increased a bit and the Nitrates, BOD and the COD levels had decreased in the treated effluent when compared to the raw effluent sample analyzed.

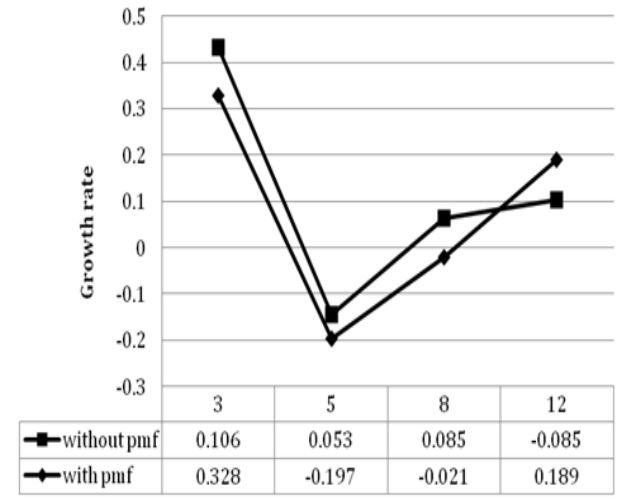

Figure 3 Growth kinetics of Desmococcus olivaceous in the effluent contained in both the photo bioreactors with and without pulsed magnetic field.

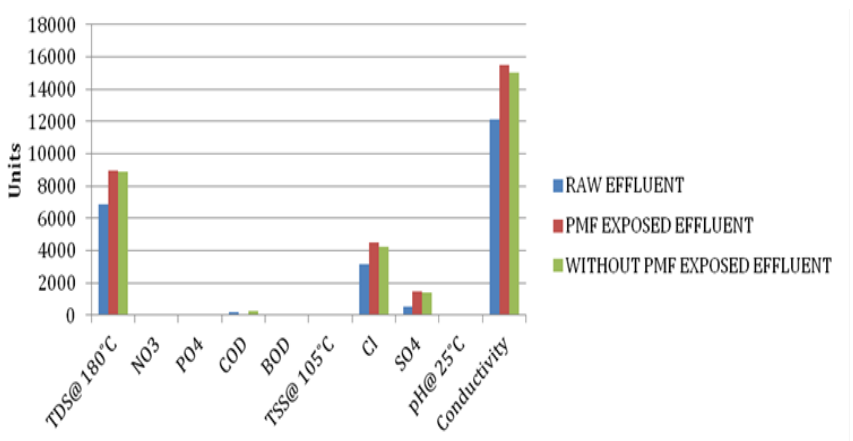

Figure 4 Comparative study of the physicochemical analysis in Desmococcus olivaceous. Few physicochemical parameters were analysed for the following sample.

i. Raw effluent collected from the industry

ii. Effluent treated with algae in the presence of PMF

iii. Effluent treated with algae in the absence of PMF.

Table 4 Growth rate of Desmococcus olivaceous $\left(\times 10^{4}\right)$

\begin{tabular}{|c|c|c|c|c|c|c|}
\hline Day & $\begin{array}{l}\text { Cell Count } \\
\text { (PMF) } \\
{\left[{ }^{*} 10^{4} \text { Cells } / \mathrm{ml}\right]}\end{array}$ & $\begin{array}{l}\text { Natural log } \\
\text { values, In } \\
\text { (PMF) }\end{array}$ & $\begin{array}{l}\text { Growth rate, } \\
\mu(\text { PMF) } \\
\left(\text { day }^{-1}\right)\end{array}$ & $\begin{array}{l}\text { Cell Count } \\
\text { (without PMF) } \\
{\left[* 10^{4} \text { Cells } / \mathrm{ml}\right]}\end{array}$ & $\begin{array}{l}\text { Natural log } \\
\text { values, In } \\
\text { (Without PMF) }\end{array}$ & $\begin{array}{l}\text { Growth rate, } \mu \\
\text { (Without PMF) (day-1) }\end{array}$ \\
\hline I & 28 & 3.314 & - & 40 & 3.688 & - \\
\hline 3 & 53 & 3.97 & 0.328 & 50 & 3.901 & 0.106 \\
\hline 5 & 36 & 3.576 & -0.197 & 55 & 4.007 & 0.053 \\
\hline 8 & 33 & 3.511 & -0.021 & 71 & 4.262 & 0.085 \\
\hline 12 & 71 & 4.269 & 0.189 & 50 & 3.921 & -0.085 \\
\hline
\end{tabular}


Table 5 Physicochemical parameters of the effluent treated by Desmococcus olivaceous under the exposure of Pulsed Magnetic Field (Test) of $3 \mathrm{mG}$ and without any exposure (Control)

\begin{tabular}{|c|c|c|c|c|c|}
\hline S. No & Parameters & $\begin{array}{l}\text { Raw } \\
\text { effluent }\end{array}$ & $\begin{array}{l}\text { PMF exposed } \\
\text { effluent }\end{array}$ & Without PMF exposed effluent & Unit \\
\hline I & Total dissolved solids@180 C & 6897 & 8990 & 8900 & $\mathrm{mg} / \mathrm{L}$ \\
\hline 2 & Nitrate as $\mathrm{NO}_{3}$ & 77 & 45.2 & 39.8 & $\mathrm{mg} / \mathrm{L}$ \\
\hline 3 & Phosphate as $\mathrm{PO}_{4}$ & 4.3 & 34.2 & 21 & $\mathrm{mg} / \mathrm{L}$ \\
\hline 4 & COD & 202 & 80 & 240 & $\mathrm{mg} / \mathrm{L}$ \\
\hline 5 & BOD@ $27^{\circ} \mathrm{C}$ for 3 days & 50 & 13 & 39 & $\mathrm{mg} / \mathrm{L}$ \\
\hline 6 & Total Suspended Solids@ $@ 105^{\circ} \mathrm{C}$ & 7 & 10 & 12 & $\mathrm{mg} / \mathrm{L}$ \\
\hline 7 & Chloride as $\mathrm{Cl}$ & 3185 & 4507.25 & 4262.3 & $\mathrm{mg} / \mathrm{L}$ \\
\hline 8 & Sulphate as $\mathrm{SO}_{4}$ & 519 & 1453.5 & 1429.95 & $\mathrm{mg} / \mathrm{L}$ \\
\hline 9 & $\mathrm{pH} @ 25^{\circ} \mathrm{C}$ & 2.82 & 3.65 & 2.74 & - \\
\hline 10 & Conductivity@25ㄷ C & 12130 & 15480 & 15050 & $\mu \mathrm{mhos} / \mathrm{cm}$ \\
\hline
\end{tabular}

\section{Conclusion}

The PMF technology is effective in increasing the biomass yield to more than $15 \%$ than any other conventional methods and it is cost effective. The algal culture along with the PMF exposure is found to be significantly reducing the BOD to $13 \mathrm{mg} / \mathrm{L}$, COD to $80 \mathrm{mg} / \mathrm{L}$ and Nitrates to $45.2 \mathrm{mg} / \mathrm{L}$ and also other parameters of the secondary treated dye effluent. A colour change has been observed during this process. Henceforth, the PMF technology has potential advantages in wastewater treatment, dye degradation, and it also improves the biomass production in large scale algae manufacturing units.

\section{Acknowledgements}

Authors express their sincere gratitude to the management of Sri Venkateswara College of Engineering, Sriperumbudur, TamilnaduIndia and also to the management of Phycospectrum Environmental Research Centre, Chennai-India for permitting them to carry out this research work.

\section{Conflict of interest}

The author declares no conflict of interest.

\section{References}

1. Rita Kant. Textile dyeing industry an environmental hazard. Natural Science. 2012;4(1):22-26.

2. KoSa. Dictionary of Fiber \& Textile Technology. Han'guk Munye Haksul Chŏjakkwŏn Hyŏphoe, USA; 2009. 258 p.

3. Chimezie Jason Ogugbue, Thomas Sawidis. Bioremediation and detoxification of synthetic wastewater containing triarylmethane dyes by Aeromonashydrophila isolated from industrial effluent. Biotechnology Research International. 2011;11:1-11.

4. Rodríguez Couto S. Dye removal by immobilized fungi. Biotechnol $A d v .2009 ; 27(3): 227-235$.

5. Sivasubramanian V, Subramanian VV, Leela PriyaT, et al. Application of pulsed magnetic field in improving the quality of algal biomass. $J J$ Algal Biomass Utln. 2010;1(4):1-9.
6. Swetha C, Sirisha K, Swaminathan D, et al. Study on the treatment of dairy effluent using Chlorella vulgaris and production of bio-fuel (Algal treatment of dairy effluent). BTAIJ. 2016;12(1):12-17.

7. Hala Yassin El-Kassas, Laila Abdelfattah Sallam. Bioremediation of the textile waste effluent by Chlorella vulgaris. Egyptian Journal of Aquatic Research. 2014;40:301-308.

8. David C Jiles. Introduction to Magnetism and Magnetic Materials. 2nd ed. USA: CRC Press; 1998. 570 p.

9. Rothwell EJ, Cloud MJ. Electromagnetics. USA: Taylor \& Francis; 2010. 23 p.

10. Hunt RW, Zavalin A, Bhatnagar A, et al. Electromagnetic biostimulation of living cultures for biotechnology, biofuel and bioenergy applications. Int J Mol Sci. 2009;10(10):4515-4558.

11. Pazur Alexander, Scheer Hugo. The growth of freshwater green algae in weak alternating magnetic fields of $7.8 \mathrm{~Hz}$ frequency. Zietschrift fuer Naturforschung Section C Journal of Biosciences. 1992;47 (9-10):690694.

12. Jack R Laundon. Desmococcusolivaceus-the name of the common subaerial green alga. Taxon. 1985;34:671-672.

13. Jeffrey D Palmer, Douglas E Soltis, Mark W Chase. The plant tree of life: an overview and some points of view. Am J Bot. 2004;91(10):14371445 .

14. Webb AG. Radiofrequency microcoils for magnetic resonance imaging and spectroscopy. J Magn Reson. 2013;229:55-66.

15. Robert A Andersen. Algal culturing techniques. First ed. London, UK: Elsevier Academic Press; 2005. 578 p.

16. Bosma R, Vermuë MH, Tramper J, et al. Towards increased microalgal productivity in photo-bioreactors. International Sugar Journal. 2010;112:74-85.

17. Patil PN, Sawant DV, Deshmukh RN. Physico-chemical parameters for testing of water-A review. International Journal of Environmental Sciences. 2012;3(3):1194-1207.

18. David Halliday, Robert Resnick, Jearl Walker. Fundamentals of Physics. 10th ed. USA; 1960. 300 p.

19. Haase J, Steglich F, Eckert D, et al. High-field NMR in pulsed magnets. Solid State Nucl Magn Reson. 2003;23(4):263-265. 